\title{
Immobilization of Alkaline Collagenase from Bacillus subtilis onto Sulfonated Polystyrene Nanospheres for Hydrolysis of Tilapia Collagen
}

\author{
Ling Zhang, ${ }^{1,2}$ Xiaocui Yang, ${ }^{1}$ Kaijun Xiao $\mathbb{D}^{1},{ }^{1}$ Yuyi Lu, ${ }^{2}$ Chunhai Li, ${ }^{2}$ and Zijin Zhang ${ }^{2}$ \\ ${ }^{1}$ School of Food Sciences and Engineering, South China University of Technology, Guangzhou 510640, Guangdong, China \\ ${ }^{2}$ College of Biological and Food Engineering, Guangdong University of Petrochemical Technology, \\ Food Science Innovation Team of Guangdong Higher Education Institutes, Maoming 525000, Guangdong, China
}

Correspondence should be addressed to Kaijun Xiao; fekjxiao@scut.edu.cn

Received 10 April 2019; Accepted 17 July 2019; Published 26 September 2019

Academic Editor: Antoni Szumny

Copyright (c) 2019 Ling Zhang et al. This is an open access article distributed under the Creative Commons Attribution License, which permits unrestricted use, distribution, and reproduction in any medium, provided the original work is properly cited.

\begin{abstract}
The structure of an alkaline protease from Bacillus subtilis used by a tilapia collagen peptide manufacturer was analyzed, and the technology of the enzyme immobilized by sulfonated polystyrene (SPS) nanoparticles was studied. The particle size distribution, SEM, EDS, TEM, and FT-IR spectroscopy of the carrier before and after immobilization were analyzed. The results showed that the molecular weight of the purified enzyme protein was $31.0 \mathrm{kDa}$. The amino acid sequence with a consistency of $64.04 \%$ and one three-dimensional structure simulation diagram of the purified enzyme protein were obtained by LC-MS-MS, which suggested that the protein might belong to subtilisin. The optimal immobilization conditions were as follows: the volume ratio of the immobilization carrier to the enzyme was $3: 50(\mathrm{~mL}: \mathrm{mL})$, the immobilized temperature was $25^{\circ} \mathrm{C}$, and the system $\mathrm{pH}$ was 4.5 . Under this condition, the immobilization ratio of collagenase was $73.48 \%$, the specific activity was $274.05 \mathrm{U} / \mu \mathrm{g}$, and the specific activity of the immobilized enzyme was about $53.74 \%$ that of the free enzyme. The average particle size of SPS nanospheres was $155.1 \mathrm{~nm}$. The characterization results of SEM, EDS, TEM, and FT-IR spectroscopy showed that the collagenase was successfully immobilized onto SPS nanospheres. The experimental results also showed that the collagenase could be immobilized effectively under the optimal conditions by using SPS nanospheres, and the operation process was simple, feasible, and of low cost with good prospect of industrial application.
\end{abstract}

\section{Introduction}

In recent years, collagen hydrolysate and polypeptide have been widely used in biology, medicine, food, cosmetics, and so on, whose function has been increasingly recognized and highly valued because of the continuous study of the structure and properties of collagen [1-3]. At present, enzyme technology is considered to be the most effective way to hydrolyze collagen $[4,5]$. Collagenase, which can be produced by many tissues and cells of various microorganisms and animals, especially under pathological conditions, is a kind of enzyme that specifically degrades the collagen helix or gelatin without acting on other proteins [6]. A large amount of collagenase can be obtained by microbial fermentation, as compared to the low yield extracted from the animal or fish viscera, which is thought to be an effective way to solve the growing industrial application demand $[7,8]$. Bacillus subtilis is a traditional high-yield strain for producing alkaline protease, and the enzyme has become a hot spot in protease research for the characteristics of high temperature, alkali resistance, etc. $[9,10]$. No matter what the source of the enzyme is, generally speaking, the crude enzyme is obtained at the beginning. A series of separation and purification methods are needed to get pure enzymes.

Immobilized enzyme technology is an effective way to overcome deficiencies of the free enzyme, which can improve the stability and recycling of the enzyme, save the usecost of the enzyme, and improve the feasibility of the application of the enzyme in scale [11]. As a new carrier of the immobilized enzyme, nanomaterials have the characteristics 
of minor pore size, large specific surface area, large surface binding energy, and easy integration with the enzyme steadily, which can effectively improve the enzyme load and the stability of enzymes [12]. In recent years, polystyrene has been not only widely used in light industry, daily decoration, lighting indication fields, and so on but also applied as a new carrier to enzyme immobilization technology $[13,14]$.

When the team worked with a local tilapia collagen peptide producer to study how to reduce the production cost, we decided to use immobilized enzyme technology to save the cost of the enzyme. We found that sulfonated polystyrene (SPS) nanospheres are a good immobilized material with simple processing, low cost, good corrosion resistance, small pore size, large specific surface area, and good biocompatibility [15], but also there are few studies on SPS nanospheres at present, and especially their application in food industry is very rare. Therefore, we chose SPS nanoparticles as a carrier and carried out some related characterization works. It is a new attempt which can provide more basic data for further study of the enzyme immobilization.

\section{Materials and Methods}

2.1. Materials and Reagents. Collagen hydrolase (alkaline protease fermented by Bacillus subtilis) and tilapia skin collagen were provided by Guangdong Baiwei Bio Material Co., Ltd., Maoming, China. All reagents were of analytical pure grade and purchased from the market, such as styrene, sodium dodecyl sulfate (SDS), Coomassie Brilliant Blue G-250, potassium persulfate, concentrated sulfuric acid, sodium hydroxide, citric acid, trichloroacetic acid (TCA), and potassium sodium tartrate.

2.2. Isolation and Purification of Collagen Hydrolase. Ammonium sulfate precipitation is divided into two steps: the first one is to remove the impure protein (in precipitation) and the second one is to retain the precipitate to obtain the purified enzyme protein [16]. The initial enzyme solution of $25 \mathrm{~mL}$ was extracted and precipitated by ammonium sulfate with a saturation of $20 \%$ and $40 \%$, respectively. The enzyme protein was precipitated by centrifugation, then dialyzed many times with a dialysis bag with a cutoff molecular weight of 8000-14000 Da, and dehydrated by polyethylene glycol 20000 [17, 18]. The concentrated enzyme protein was purified by a full-automatic polysaccharide and protein purification system (PS-P, China) with glucan gel G-759 as a column chromatography filler afterwards, using $10 \mathrm{mmol} / \mathrm{L}$, pH 5.5 phosphate buffer as equilibrium and elution liquid, and $20 \%$ ethanol for rinsing. When the elution peak began to appear, the peak time was recorded, and the eluted enzyme was collected $(3 \mathrm{~mL} / \mathrm{tube})$. The enzyme collected repeatedly was first concentrated with polyethylene glycol 20000 and then freeze-dried into powder and stored hermetically at low temperature for further use.
2.3. Determination of Molecular Weight and Structure Simulation of the Purified Enzyme Protein. The molecular weight of the purified enzyme protein was determined by SDSPAGE (1645050, US) [19].

The amino acid sequence of the enzyme protein was determined by LC-MS-MS (Q Exactive, US), using the bands separated by SDS-PAGE gel electrophoresis and hydrolyzed by trypsin $[20,21]$. Liquid chromatographic column information: $300 \mu \mathrm{m}$ i.d. $\times 5 \mathrm{~mm}$, packed with Acclaim PepMap RSLC C18, $5 \mu \mathrm{m}, 100 \AA$, nanoViper; mobile phase A: $0.1 \%$ formic acid; mobile phase B: $0.1 \%$ formic acid and $80 \%$ CAN; flow rate: $300 \mathrm{~nL} / \mathrm{min}$; and analysis time of each group: $60 \mathrm{~min}$. The separated peptide entered the Q Exactive mass spectrometer directly for online detection. Parameters of MS 1: resolution: 70,000; AGC target: 3e6; maximum IT: $40 \mathrm{~ms}$; and scan range: 350 to $1800 \mathrm{~m} / \mathrm{z}$. Parameters of MS 2: resolution: 17,500; AGC target: 1e5; maximum IT: $60 \mathrm{~ms}$; TopN: 20; and NCE/stepped NCE: 27. The three-dimensional structure of the enzyme protein was modeled by MM File Conversion online (https://www.proteinmodelportal.org/ query/uniprot/) and retrieved by Mascot. Finally, the blast comparison was used on the NCBI database to analyze the homology of the protein. The secondary structure and tertiary structure of the enzyme protein were analyzed by Phyre2, NCBI, SWISS-MODEL, and PyMOL.

2.4. Preparation of Sulfonated Polystyrene. The styrene (St) was first soaked in $\mathrm{NaOH}$ aqueous solution (10 wt.\%), and after 24 hours, it was washed several times with distilled water. The treated St was rotary evaporated under reduced pressure at $60^{\circ} \mathrm{C}$. SDS $(0.2 \mathrm{~g})$ and $\mathrm{Na}_{2} \mathrm{CO}_{3}(0.1 \mathrm{~g})$ were weighed and dissolved in $300 \mathrm{~mL}$ distilled water. The resulting solution was transferred to the three-neck flask and purged with nitrogen for $30 \mathrm{~min}$. Subsequently, $30 \mathrm{~mL}$ of treated St was added to the above solution under strong stirring, and the solution was heated to $60^{\circ} \mathrm{C}$. After $30 \mathrm{~min}$, potassium persulfate aqueous solution $(15 \mathrm{~mL}, 0.23 \mathrm{mmol} / \mathrm{L})$ was introduced into it [22]. The polymerization reaction was conducted at $75^{\circ} \mathrm{C}$ for $20 \mathrm{~h}$. After cooling to room temperature, the product was alternately washed with $95 \%$ ethanol and distilled water. Afterwards, the product was purified by reduced-pressure rotary evaporation at $60^{\circ} \mathrm{C}$ and dried at $60^{\circ} \mathrm{C}$ for further use [23].

The above polystyrene (PS) powder $(1.0 \mathrm{~g})$ was dispersed into concentrated $\mathrm{H}_{2} \mathrm{SO}_{4}(40 \mathrm{~mL}, 98 \%)$ by ultrasonication. An ultrasonic cleaning tank was used for ultrasonication for $20 \mathrm{~min}$ at room temperature. The sulfonation reaction was conducted at room temperature for $24 \mathrm{~h}$. The product was thoroughly washed with distilled water and ethanol and dried at $60^{\circ} \mathrm{C}$ using a vacuum oven. After drying, the product was dispersed into distilled water by ultrasonication, and the sulfonated polystyrene emulsion $(40 \mathrm{mg} / \mathrm{mL})$ was made.

\subsection{Study on Immobilization of Enzymes}

2.5.1. Immobilization Method. SPS nanosphere emulsion was treated under ultrasonication for $30 \mathrm{~min}$, and a certain amount of it was diluted 100 times with phosphate buffer. 
The enzyme was diluted 20 times with phosphate buffer. The diluted enzyme solution and SPS emulsion were oscillated and mixed in a test tube. After a certain reaction time at room temperature, the reactants were separated by centrifugation at the speed of $16000 \mathrm{r} / \mathrm{min}$ for $15 \mathrm{~min}$; the supernatant was collected and stored at $4{ }^{\circ} \mathrm{C}$ to determine the immobilization ratio, and the precipitate was collected and freeze-dried to measure immobilized enzyme activity [24].

2.5.2. Optimization of Immobilized Process. A single-factor experiment was carried out, and other conditions were determined. The effects of four factors, such as the volume ratio of the immobilization carrier to the enzyme, immobilization time, temperature, and $\mathrm{pH}$, were studied by using immobilization ratio and specific activity of protein as indicators. According to the results of the single-factor test, orthogonal experiments were used to optimize the immobilization conditions.

\section{(1) Single-Factor Experiment}

(1) Effects of the Volume Ratio of the Immobilization Carrier to the Enzyme. In the test tubes, 1\% SPS emulsion $(2 \mathrm{~mL}, 3 \mathrm{~mL}, 4 \mathrm{~mL}, 5 \mathrm{~mL}, 6 \mathrm{~mL}$, and $7 \mathrm{~mL}$ ) after ultrasonic treatment was added, respectively, to $5 \%$ enzyme solution $(10 \mathrm{~mL})$, reacting for $8 \mathrm{~min}$ after shaking at $25^{\circ} \mathrm{C}$. After centrifugation, immobilizing effects could be compared.

(2) Effects of Immobilization Time. In the test tubes, $1 \%$ SPS emulsion ( $4 \mathrm{~mL}$ ) after ultrasonic treatment was added to $5 \%$ enzyme solution $(10 \mathrm{~mL})$, reacting for $2-10 \mathrm{~min}$ after shaking at $25^{\circ} \mathrm{C}$. After centrifugation, immobilizing effects could be compared.

(3) Effects of Immobilization Temperature. In the test tubes, 1\% SPS emulsion ( $4 \mathrm{~mL}$ ) after ultrasonic treatment was added to $5 \%$ enzyme solution $(10 \mathrm{~mL})$, reacting for $8 \mathrm{~min}$ after shaking at $15^{\circ} \mathrm{C}$, $20^{\circ} \mathrm{C}, 25^{\circ} \mathrm{C}, 30^{\circ} \mathrm{C}$, and $35^{\circ} \mathrm{C}$. After centrifugation, immobilizing effects could be compared.

(4) Effects of Immobilization $p H$. The enzyme and SPS emulsion were diluted 20 times and 100 times with phosphate buffer of different $\mathrm{pH}$ (3.2 6.4), respectively. In the test tubes, 1\% SPS emulsion $(4 \mathrm{~mL})$ after ultrasonic treatment was added to $5 \%$ enzyme solution $(10 \mathrm{~mL})$, reacting for $8 \mathrm{~min}$ after shaking at $25^{\circ} \mathrm{C}$. After centrifugation, immobilizing effects could be compared.

(2) Orthogonal Test

According to the results of single-factor experiments, three factors, such as the volume ratio of the immobilization carrier to the enzyme, immobilization temperature, and immobilization system $\mathrm{pH}$, were chosen for study, and $L_{9}(3)^{3}$ orthogonal tests were carried out to obtain the optimal immobilization conditions. The factor-level table is shown in Table 1.
2.6. Determination of the Enzyme Immobilization Ratio. The content of enzyme protein was determined by the Coomassie Brilliant Blue method, and the immobilization ratio $(Y)$ of protein was calculated using the following equation:

$$
Y=\left[\frac{\left(m_{0}-m_{1}\right)}{m_{0}}\right] \times 100 \%,
$$

where $m_{0}(\mathrm{mg})$ is the total protein quality of enzyme solution before immobilization and $m_{1}(\mathrm{mg})$ is the total protein mass of residual liquid after immobilization.

2.7. Determination of Enzyme Activity. First, the modified biuret method was used to determine the concentration of peptides in this experiment, and the operation was based on the patent "A Method for the Determination of Collagen Peptide in Tilapia by Biuret Method" [25]. The peptide content was calculated according to the following equation:

$$
M=\frac{A}{b} \times c \times d \times V_{1},
$$

where $M(\mathrm{mg})$ is the peptide content in the reaction system, $A$ is the absorbance, $b$ is the coefficient of the standard curve, $c(11 / 1)$ is the dilution multiple of the reacting solution after precipitating protein, $d$ is the dilution multiple of the reacting solution after adjusting $\mathrm{pH}$, and $V_{1}(\mathrm{~mL})$ is the total volume in the reaction system.

The second step was to determine the activity of the enzyme. The reaction conditions for the determination of enzyme activity were as follows: at $60^{\circ} \mathrm{C}$, the concentration of collagen in the reaction system was $10 \%$ and the volume concentration of the original enzyme solution was $100 \mathrm{ppm}$, reacting for $10 \mathrm{~min}$. The enzyme activity was defined as that, under the above conditions, one enzyme activity unit (U) was required for $1 \mu \mathrm{g}$ polypeptide produced by hydrolyzing collagen of fish skin with the original enzyme solution per minute. The enzyme activity was calculated according to the following equation:

$$
Q=\frac{M \times 10^{3}}{T} \times \frac{1}{V_{2}},
$$

where $Q(\mathrm{U})$ is the enzyme activity, $M(\mathrm{mg})$ is the peptide content in the reaction system, $T$ ( $\mathrm{min}$ ) is the reaction time, and $V_{2}(\mathrm{~mL})$ is the volume of the original enzyme solution added in the reaction system.

2.8. Determination of Specific Activity of Immobilized Enzymes. The specific activity of immobilized enzymes was calculated using the following equation:

$$
S=\frac{Q}{\left(m_{0}-m_{1}\right)}
$$

where $S(\mathrm{U} / \mu \mathrm{g})$ is the specific activity, $Q(\mathrm{U})$ is the enzyme activity, $m_{0}(\mathrm{mg})$ is the total protein quality of enzyme solution before immobilization, and $m_{1}(\mathrm{mg})$ is the total protein mass of residual liquid after immobilization. 
TABLE 1: Factors and levels of the orthogonal test.

\begin{tabular}{lccc}
\hline & A & B & C \\
Level & $\begin{array}{c}\text { Volume ratio of the immobilization carrier to the } \\
\text { enzyme }(\mathrm{mL}: \mathrm{mL})\end{array}$ & $\begin{array}{c}\text { Immobilization temperature }\left({ }^{\circ} \mathrm{C}\right) \\
\mathrm{pH} \text { of the immobilized system }\end{array}$ \\
\hline 1 & $3: 50$ & 20 & 3.5 \\
2 & $4: 50$ & 25 & 4.0 \\
3 & $5: 50$ & 30 & 4.5 \\
\hline
\end{tabular}

\subsection{Characterization of Sulfonated Polystyrene Nanospheres and Immobilized Enzymes}

2.9.1. Analysis of Particle Size Distribution of SPS Nanospheres. The particle size distribution of SPS nanospheres was determined by a nanoparticle analyzer (SZ-100Z, Japan). It worked under the condition that the scattering angle was $90^{\circ}$, the stent temperature was $25.2^{\circ} \mathrm{C}$, and the dispersion medium was water.

2.9.2. Scanning Electron Microscopy (SEM) and Energy Spectrum Analysis. The morphology of SPS nanospheres and immobilized enzymes was studied by a scanning electron microscope (JSM-6510LV, Japan). The SPS emulsion was diluted 100 times with distilled water, dropped on tin foil, dried, and then subjected to gold spray treatment. The samples were observed under a scanning electron microscope of which the working voltage was set to $1 \mathrm{kV}$ [26]. The freeze-dried immobilized enzyme was dispersed in distilled water and determined by the same method.

2.9.3. Transmission Electron Microscope (TEM). The solution of SPS nanospheres was dialyzed, and the produce obtained was dried at $50^{\circ} \mathrm{C}$. The samples were observed by a transmission electron microscope (H7650, Japan), and the operating voltage was $200 \mathrm{kV}$. The immobilized enzyme was dissolved in distilled water and determined by the same method.

2.9.4. Fourier Transform Infrared (FT-IR) Spectroscopy. The dry SPS nanoparticles and immobilized enzyme were, respectively, made into suitable sized wafers by the $\mathrm{KBr}$ powder compaction method. In the measurement range of $4000-450 \mathrm{~cm}^{-1}$, the wafers were measured by a Fourier transform infrared spectrometer (Nicolet 6700, US). The infrared spectrum of the prefixed material and immobilized enzyme was obtained [27].

2.10. Experimental Data Plotting and Mathematical Statistical Methods. Single-factor and orthogonal experiments were done three times in parallel, taking the mean value. The SPSS 20. 0 statistical analysis software was used to analyze the variance of data, and Origin 8.5 was applied to draw.

\section{Results and Discussion}

3.1. Molecular Weight Determination of the Purified Enzyme. The result of gel electrophoresis bands is shown in Figure 1. As seen in the chart, the purified enzyme solution has only one distinct single zone, which indicates that the purification method adopted in the experiment achieved the ideal purification effect. According to the relative mobility rate and standard curve of the sample, the molecular weight of enzyme protein after separation and purification is calculated to be $31.0 \mathrm{kDa}$.

3.2. Amino Acid Sequence and Structure Simulation of Collagen Hydrolase. Referring to documents [28, 29], the protein sequence of the purified collagen hydrolase is obtained after sequencing, and then the mass number of collagen protein hydrolysate is retrieved from the Mascot database to obtain several suspicious proteins. After online blast matching, a protein with $100 \%$ homology was obtained and identified as the Bacillus subtilis protease (accession number: Q45299-BACLI). Its amino acid sequence, as shown in Figure 2, consists of 379 amino acids with a molecular weight of $39082 \mathrm{Da}$. The molecular formula of the enzyme protein is $\mathrm{C}_{1715} \mathrm{H}_{2730} \mathrm{~N}_{472} \mathrm{O}_{548} \mathrm{~S}_{11}$, the total number of atoms is 5476, and the isoelectric point is 8.66. According to the amino acid sequence, the enzyme was identified as alkaline protease because the amino acid residue (Arg Lys) was 32 and the acidic amino acid residue (Asp Glu) was 29. It is a hydrophilic protease for the total hydrophobic average (GRAVY) of -0.030 . Its aliphatic amino acid index is 81.82 . According to the criterion of stable protein (unstable index $<40$ ), it can also be judged as the stable protein as its unstable index (II) is 15.63. The N-terminal of the enzyme is $\mathrm{M}$ (Met). The content of alanine, glycine, valine, and serine is $11.6 \%, 11.3 \%, 11.1 \%$, and $10.8 \%$, respectively. The content of cysteine is the lowest $(0.3 \%)$.

Then, using c3whiA as the template, the Phyre2 server was used to predict the secondary structure of the enzyme protein molecule. As shown in Figure 3, the consistency between the predicted structure and the submitted target protein amino acid sequence is $64.04 \%$, the information about the possible locations of $\alpha$-helix and $\beta$-fold can be obtained, and the result is credible.

The secondary structure of the enzyme was analyzed by the SOPMA online program. As shown in Figure 4, the secondary structure of the enzyme contains $32.98 \%$ $\alpha$-helix structures, $20.58 \% \beta$-fold structures, $9.76 \% \beta$-turn structures, and $36.68 \%$ irregular curl structures. The $\alpha$-helix structure and irregular crimping structure exist alternately, which are the main part of the whole structure of the protease, and the extended long chain is uniformly distributed in the whole chain. This distribution is beneficial to the stability of the enzyme structure. 


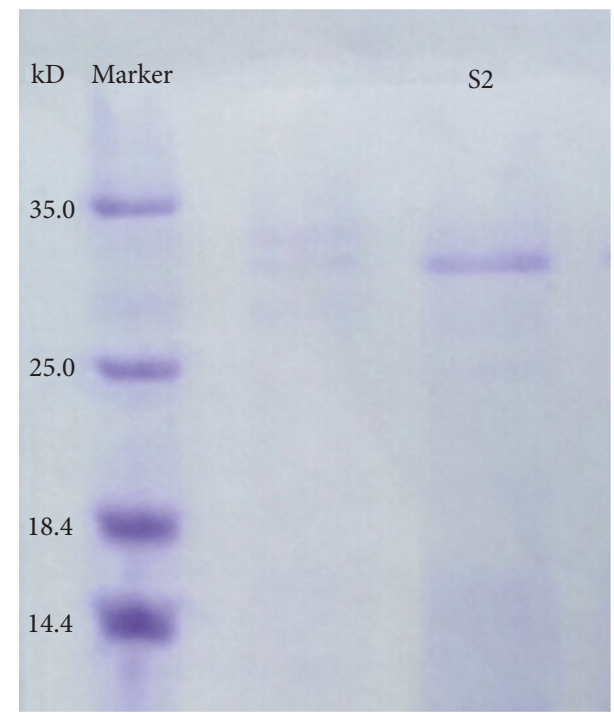

FIGURE 1: Gel electrophoresis bands of marker and purified collagenase (S2).

1 MMRKKSFWLG MLTAFMLVFT MAFSDSASAA QPAKNVEKDY IVGFKSGVKT 51 ASVKKDIIKE SGGKVDKQFR IINAAKAKLD KEALKEVKND PDVAYVEEDH 101 VGHGLGQTVP YGIPLIKADK VQAQGFKGAN VKVAVLDTGI QASHPDLNVV 151 GGASFVAGEA YNTDGNGHGT HVAGTVAALD NTTGVLGVAP SVSLYAVKVL 201 NSSGSGSYSG IVSGIEWVTT NGMDVINMSL GGASGSTAMK QAVDNAYARG 251 VVVVAAAGNS GSSGNTNTIG YPAKCDSVIP VGGEDSNSNR SSFSSVGAEL 301 EVMAPVSGVY STYPTNTYTT LNGTSMASPH VAGTSALILS KHPNLSASQV 351 RNRLSRTATY LGSSFYYGKG LINVEAAAQ

Figure 2: Amino acid sequence of the Bacillus subtilis protease (accession number: Q45299-BACLI; matched peptides are shown in bold red).

The amino acid sequence of the protein was analyzed by the Related Structures (Summary) function in NCBI, and the result showed that the protease molecule of Bacillus subtilis mainly contained a functional domain. As shown in Figure 5, the active sites of the enzyme are in the domain of $133^{\text {th }}-325^{\text {th }}$ amino acids. The specific active sites are the $137^{\text {th }}, 168^{\text {th }}, 211^{\text {th }}, 230^{\text {th }}, 259^{\text {th }}$, and $325^{\text {th }}$ amino acids. The sites with catalytic activity are the $137^{\text {th }}, 168^{\text {th }}$, and $325^{\text {th }}$ amino acids.

Using c3whiA as the template, SWISS-MODEL (http:// swissmodel.expasy.ore/) was used to predict the tertiary structure of the enzyme, and we found that the range of the residues of the enzyme molecule was from the $36^{\text {th }}$ to the $379^{\text {th }}$ amino acid. The simulated structure diagram is shown in Figure 6, and the performance is displayed in different colors in the structure, with N-terminals above and C-terminals below. Figure 6(b) is a structure diagram based on hydrophilic labeling, showing that most of the protein molecules are hydrophilic fragments and only a few are hydrophobic fragments. Figures 6(c) and 6(d) show that the positive charge of the protease residue is more than the negative charge, mainly on the surface, according to the charge-marked structure diagram.

Figure 7 is about catalytic activity sites, showing that the active site is located in the middle of the structure and is a triplet with catalytic hydrolysis of $a$-peptide bonds in internal peptide chains composed of aspartic acid $\left(137^{\text {th }}\right)$ with an acidic residue, histidine $\left(168^{\text {th }}\right)$ with an alkaline residue, and serine $\left(325^{\text {th }}\right)$ with the nucleophilic property.

\subsection{Conditions for Immobilization of Collagen Hydrolase onto Sulfonated Polystyrene Nanospheres}

3.3.1. Single-Factor Experimental Result Analysis. The influence of the volume ratio of the immobilization carrier to the enzyme, time, temperature, and $\mathrm{pH}$ on immobilization is shown in Figure 8. It can be seen from Figure 8(a) that, under the condition of a certain amount of collagenase, the immobilization ratio of the enzyme increases with the improvement of the amount of the SPS nanosphere, but the specific activity of the immobilized enzyme is continuously decreased. When the ratio of the amount of the SPS to the quantity of the emulsion reaches $5: 50$, the immobilization ratio is largest and basically stable, and the maximum value is $97.30 \%$, which indicates that when the volume of SPS emulsion is $10 \%$ of the collagenase volume, the SPS nanospheres can adsorb collagenase to the greatest extent. When the ratio reaches $2: 50$, the specific activity is largest; however, when the ratio reaches $7: 50$, the specific activity is smallest. This may be due to the influence of SPS on the activity of collagenase. Considering comprehensively, it is advisable to determine the effect of volume ratio of $4: 50$.

It can be seen from Figure 8 (b) that the change of the immobilization ratio is very weak, all up to $97 \%$ in 2 min to $10 \mathrm{~min}$, but the activity of the immobilized enzyme decreases slightly. When immobilized for $6 \mathrm{~min}$, the immobilization ratio reaches the maximum, which is $97.76 \%$. When immobilized for $4 \mathrm{~min}$, the specific activity is the highest, and after $8 \mathrm{~min}$, the specific activity decreases significantly. These indicate that the SPS has a strong adsorption capacity for collagenase and can quickly complete the immobilization process. So, $8 \mathrm{~min}$ can be chosen as the best immobilization time.

It can be seen from Figure 8(c) that the immobilization ratio changes little with the increase of temperature, while the specific activity is greatly influenced. When the temperature is $25^{\circ} \mathrm{C}$, the immobilization ratio is the highest, and when the temperature is between 15 and $25^{\circ} \mathrm{C}$, the loss of specific activity is less, but the specific activity decreases significantly when the temperature continues to rise, which may be because the high-temperature environment will destroy the active site of the enzyme, resulting in a decrease in specific activity. Therefore, $25^{\circ} \mathrm{C}$ can be determined as the best immobilization temperature.

It can be seen from Figure $8(\mathrm{~d})$ that the system $\mathrm{pH}$ has great influence on the immobilization ratio and specific activity. With the increase of $\mathrm{pH}$, the immobilization ratio decreases, while the specific activity increases first and then decreases. When the $\mathrm{pH}$ is 3.2 , the immobilization ratio reaches $96.25 \%$ and the specific activity decreases to the minimum, and when the $\mathrm{pH}$ is 5.6 , the immobilization ratio decreases to the minimum, but the specific activity reaches the maximum, which may be due to the decreased activity of 


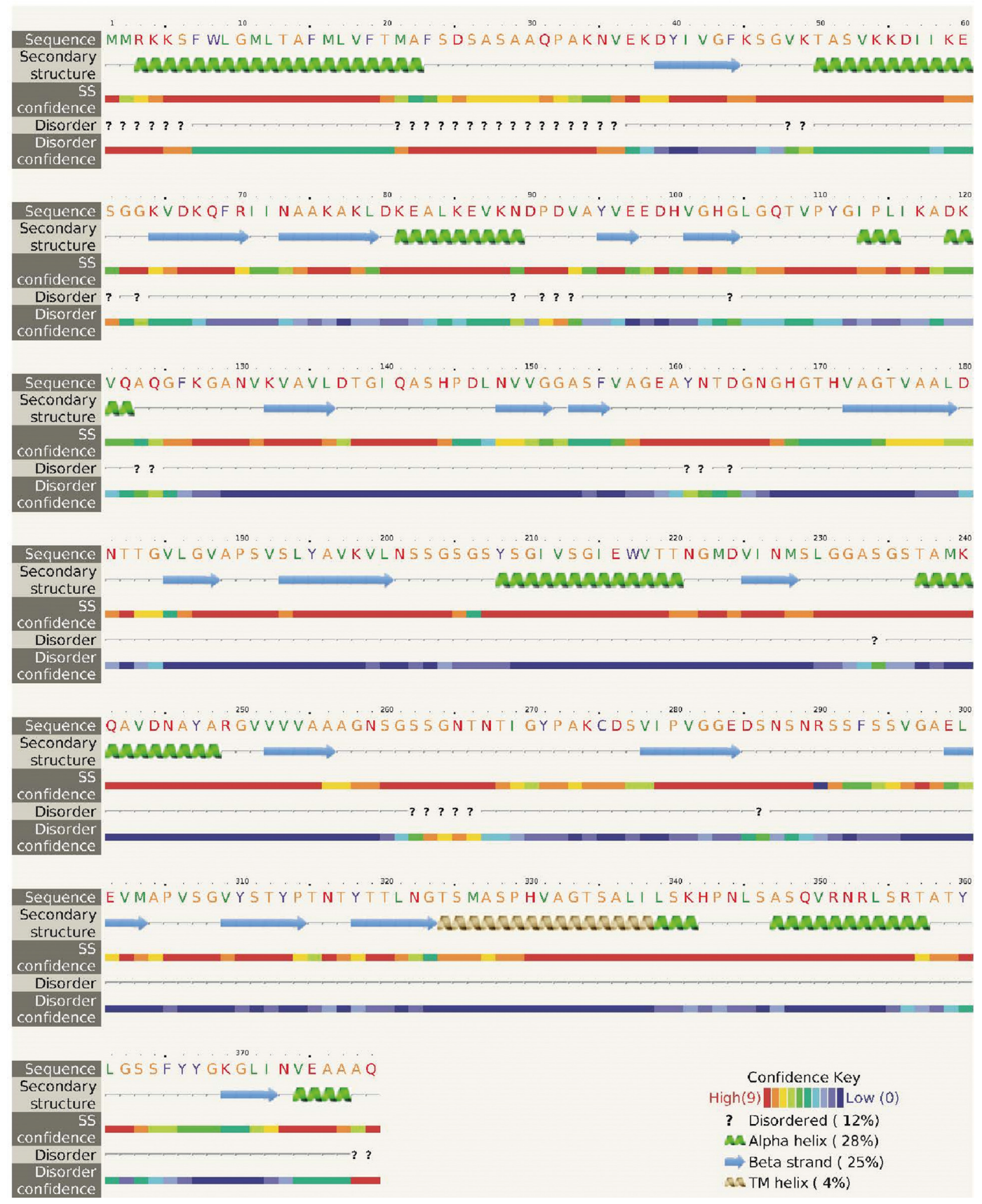

FIgURE 3: Secondary structure prediction of Bacillus subtilis by the Phyre2 Server.

the alkaline protease in a peracid environment. Therefore, pH 4.0 is considered to be an appropriate condition.

3.3.2. Orthogonal Experimental Result Analysis. According to the single-factor experimental results, considering the immobilization time has little effect on immobilization; taking $8 \mathrm{~min}$ as the best immobilization time, the $L_{9}(3)^{3}$ orthogonal optimization experiment is carried out by selecting three factors (the volume ratio of the immobilization carrier to the enzyme, immobilization temperature, and $\mathrm{pH}$ ) from four single factors. The orthogonal experimental results are shown in Table 2, and the variance analysis is shown in Table 3.

According to the orthogonal experimental results and variance analysis, if the immobilization ratio is used as the evaluation index, the optimal process combination is $\mathrm{A}_{3} \mathrm{~B}_{1} \mathrm{C}_{1}$. The influence degree of each factor on the immobilization ratio is as follows: $\mathrm{pH}>$ volume ratio of the immobilization carrier to the enzyme $>$ immobilization temperature, in which the $\mathrm{pH}$ and the volume ratio of the material and enzyme liquid are extremely significant. However, if the specific activity of the immobilized enzyme is used as the evaluation index, the best combination is 


10
$\mid$

Figure 4: Secondary structure prediction of Bacillus subtilis by the SOPMA server (h: alpha-helix; e: beta-strand; t: beta-turn; c: random coil).

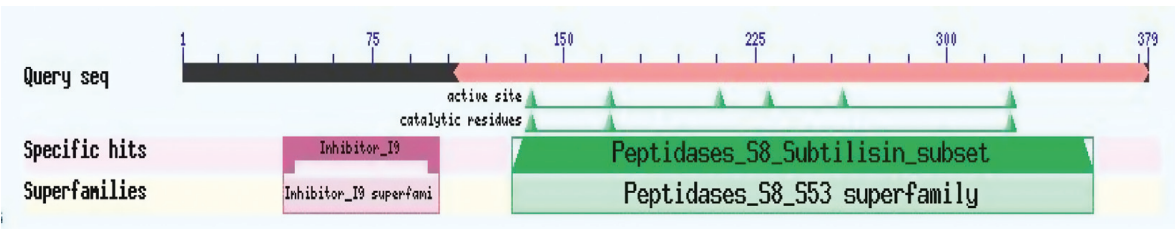

Figure 5: Characteristic fields of the Bacillus subtilis molecular sequence.

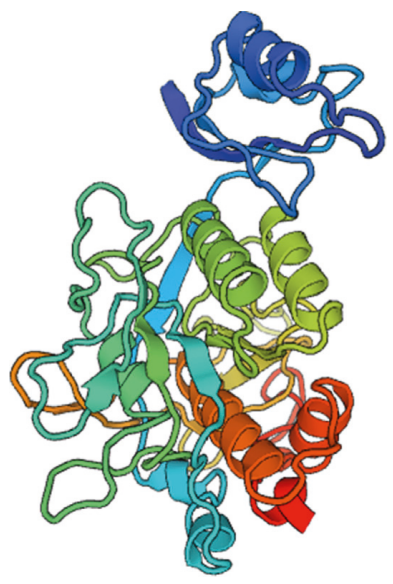

(a)

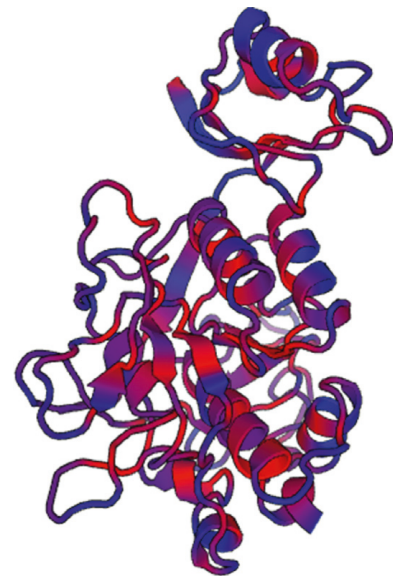

(b)

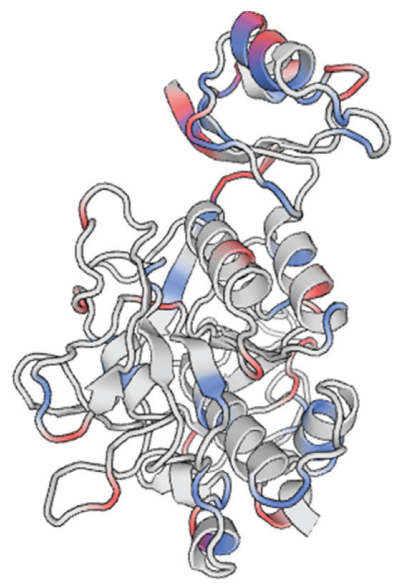

(c)

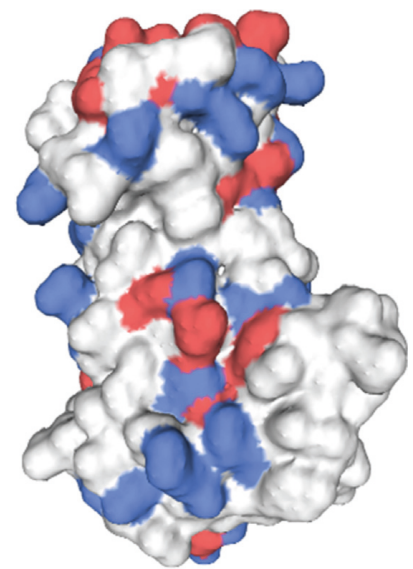

(d)

Figure 6: Tertiary structure of the Bacillus subtilis protein. (a-d) Structure diagrams marked with different colors. (a) Rainbow: (N-terminus $\longrightarrow$ C-terminus). (b) Hydrophobic: RKDENOHPYWSTGAMCELVI (least hydrophobic $\longrightarrow$ most hydrophobic). (c, d) Charged: red (negative) and blue (positive).

$A_{1} B_{2} C_{3}$. The influence degree of each factor on the specific activity of the immobilized enzyme is as follows: volume ratio of the immobilization carrier to the enzyme $>\mathrm{pH}>$ immobilized temperature, and only the influence of volume ratio of the immobilization carrier to the enzyme is extremely significant.

The two combinations of $\mathrm{A}_{3} \mathrm{~B}_{1} \mathrm{C}_{1}$ and $\mathrm{A}_{1} \mathrm{~B}_{2} \mathrm{C}_{3}$ are conducted in parallel for three validation tests, and the 


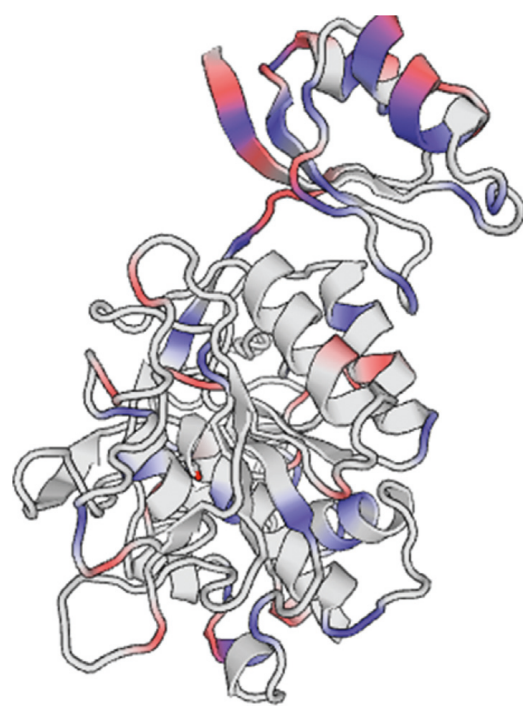

(a)

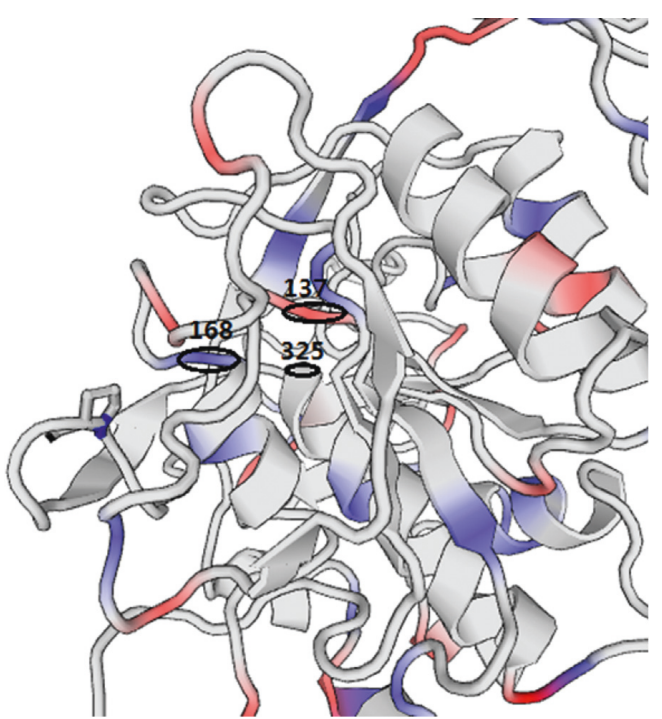

(b)

Figure 7: Active site of the Bacillus subtilis molecule.

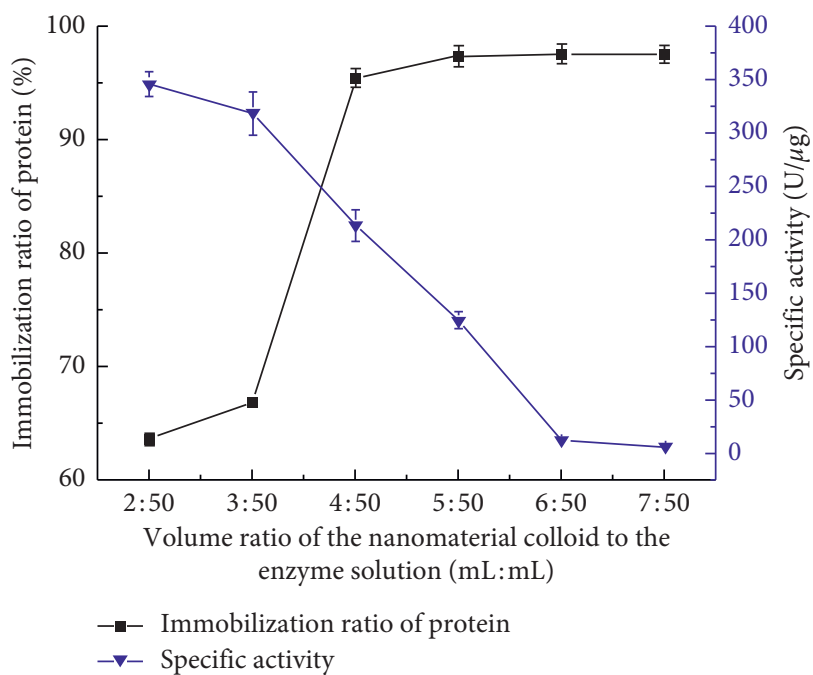

(a)

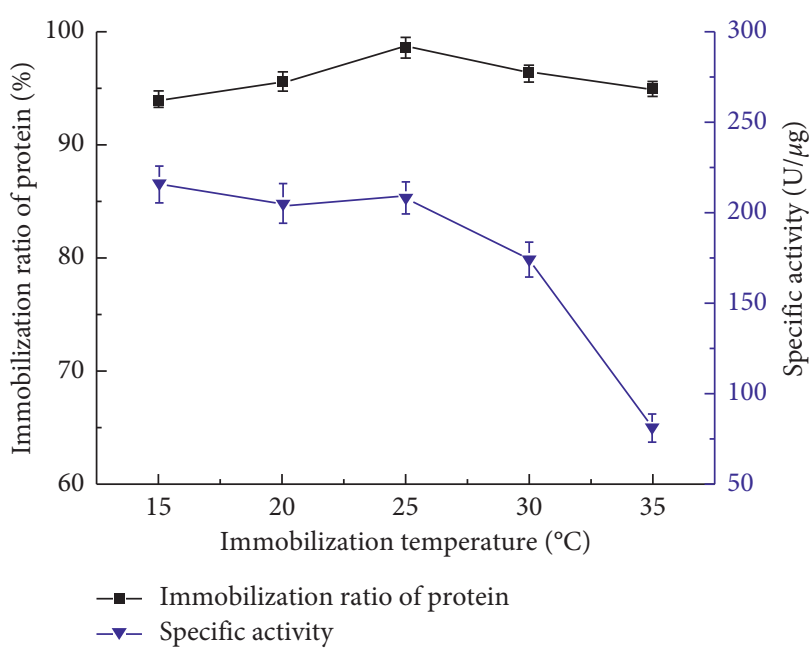

(c)

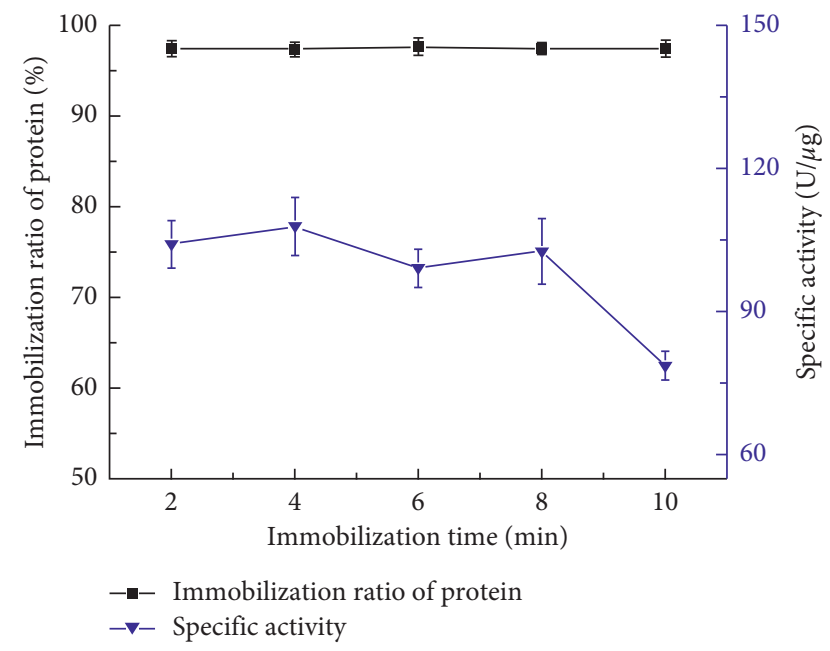

(b)

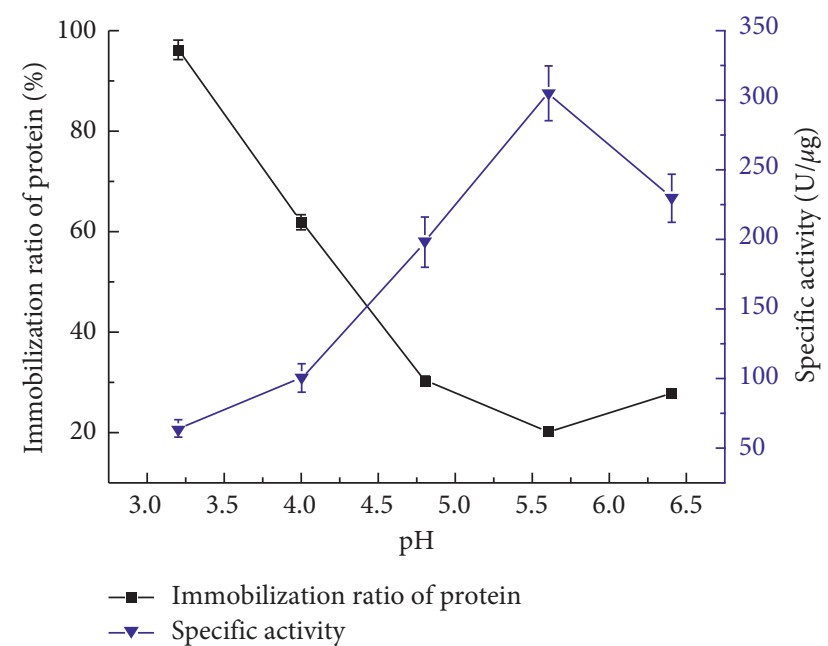

(d)

FIGURE 8: Influence of the volume ratio of the nanomaterial to the enzyme solution (a), immobilization time (b), temperature (c), and pH (d) on immobilization. 
TABLE 2: Orthogonal experimental results and analysis.

\begin{tabular}{|c|c|c|c|c|c|}
\hline Experiment number & A & $\mathrm{B}$ & $\mathrm{C}$ & Immobilization ratio of protein (\%) & Specific activity $(\mathrm{U} / \mu \mathrm{g})$ \\
\hline 1 & $1(3: 50)$ & $1(20)$ & $1(3.5)$ & $87.27 \pm 0.42$ & $203.29 \pm 14.55$ \\
\hline 2 & 1 & $2(25)$ & $2(4.0)$ & $79.33 \pm 0.49$ & $226.59 \pm 15.14$ \\
\hline 3 & 1 & $3(30)$ & $3(4.5)$ & $72.91 \pm 0.38$ & $267.33 \pm 13.02$ \\
\hline 4 & $2(4: 50)$ & 1 & 2 & $86.08 \pm 0.87$ & $169.55 \pm 14.83$ \\
\hline 5 & 2 & 2 & 3 & $80.51 \pm 0.52$ & $180.14 \pm 14.25$ \\
\hline 6 & 2 & 3 & 1 & $91.39 \pm 0.63$ & $158.30 \pm 15.54$ \\
\hline 7 & $3(5: 50)$ & 1 & 3 & $82.88 \pm 0.54$ & $143.51 \pm 19.95$ \\
\hline 8 & 3 & 2 & 1 & $94.00 \pm 0.78$ & $154.08 \pm 15.46$ \\
\hline 9 & 3 & 3 & 2 & $89.17 \pm 0.44$ & $110.21 \pm 19.44$ \\
\hline$k_{1}$-Ir & 79.84 & 85.41 & 90.89 & & \\
\hline$k_{2}-\mathrm{Ir}$ & 85.99 & 84.61 & 84.86 & & \\
\hline$k_{3}$-Ir & 88.68 & 84.49 & 78.77 & & \\
\hline$k_{1}-\mathrm{Sa}$ & 232.40 & 172.12 & 171.89 & & \\
\hline$k_{2}-\mathrm{Sa}$ & 169.33 & 186.94 & 183.41 & & \\
\hline$k_{3}-\mathrm{Sa}$ & 135.93 & 178.61 & 196.99 & & \\
\hline$R$-Ir & 8.84 & 0.92 & 12.12 & & \\
\hline$R-\mathrm{Sa}$ & 96.47 & 14.82 & 25.10 & & \\
\hline
\end{tabular}

Note: $k$-Ir means $k$ value of the immobilization ratio of protein; $R$-Ir means range value of the immobilization ratio of protein; $k$-Sa means $k$ value of specific activity; $R$-Sa means range value of specific activity.

TABLE 3: Analysis of variance.

\begin{tabular}{|c|c|c|c|c|c|c|}
\hline Indicator & Source of variation & SS & $\mathrm{df}$ & MS & $F$ & \\
\hline \multirow{6}{*}{ Immobilization ratio of protein } & Interblock & 129717.013 & 1 & 129717.013 & 121801.63 & \multirow{6}{*}{$\begin{array}{l}F_{0.05(2,11)}=3.98 \\
F_{0.01(2,11)}=7.21\end{array}$} \\
\hline & A & 237.015 & 2 & 118.508 & $111.276^{* *}$ & \\
\hline & B & 2.688 & 2 & 1.344 & 1.262 & \\
\hline & $\mathrm{C}$ & 440.833 & 2 & 220.416 & $206.966^{* *}$ & \\
\hline & Error & 11.715 & 11 & 1.065 & & \\
\hline & Total variation & 692.251 & 17 & & & \\
\hline \multirow{6}{*}{ Specific activity } & Interblock & 578160.136 & 1 & 578160.136 & 812.812 & \multirow{6}{*}{$\begin{array}{l}F_{0.05(2,11)}=3.98 \\
F_{0.01(2,11)}=7.21\end{array}$} \\
\hline & A & 28801.349 & 2 & 14400.674 & $20.245^{* *}$ & \\
\hline & $\mathrm{B}$ & 662.364 & 2 & 331.182 & 0.466 & \\
\hline & $\mathrm{C}$ & 2871.830 & 2 & 1435.915 & 2.019 & \\
\hline & Error & 7824.394 & 11 & 711.309 & & \\
\hline & Total variation & 40159.936 & 17 & & & \\
\hline
\end{tabular}

Note: * significant difference, $F \geq F_{0.05(2,11)}$; ${ }^{* *}$ extremely significant difference, $F \geq F_{0.01(2,11)}$.

TABLE 4: Results of confirmatory experiments.

\begin{tabular}{lcc}
\hline Parameter combination & Immobilization ratio of protein (\%) & Specific activity $(\mathrm{U} / \mu \mathrm{g})$ \\
\hline $\mathrm{A}_{3} \mathrm{~B}_{1} \mathrm{C}_{1}$ & $94.78 \pm 0.78$ & $162.26 \pm 14.28$ \\
$\mathrm{~A}_{1} \mathrm{~B}_{2} \mathrm{C}_{3}$ & $73.48 \pm 0.26$ & $274.05 \pm 15.52$ \\
\hline
\end{tabular}

results are shown in Table 4. The immobilization ratio of $\mathrm{A}_{3} \mathrm{~B}_{1} \mathrm{C}_{1}$ is $94.78 \%$, and the specific activity of $\mathrm{A}_{1} \mathrm{~B}_{2} \mathrm{C}_{3}$ is $268.95 \mathrm{U} / \mu \mathrm{g}$, which is larger than the maximum value appearing in the orthogonal nine sets of experiments. The results prove that the orthogonal optimization is reliable. In addition, this experiment pays more attention to the specific activity of the immobilized enzyme. Therefore, the best combination is $A_{1} B_{2} C_{3}$, in which the volume ratio of the material to the enzyme is $3: 50(\mathrm{~mL}: \mathrm{mL})$, the immobilization temperature is $25^{\circ} \mathrm{C}$, and the $\mathrm{pH}$ is 4.5 . At this time, the protein immobilization ratio is $73.48 \%$, and the immobilized enzyme specific activity is $274.05 \mathrm{U} / \mu \mathrm{g}$. Compared with the specific activity of the free enzyme of
$509.90 \mathrm{U} / \mu \mathrm{g}$, the specific activity of the immobilized enzyme is about $53.74 \%$ that of the free enzyme, indicating that the immobilization of SPS nanospheres would reduce the enzymatic activity of collagenase.

\subsection{Characterization of Sulfonated Polystyrene Nanoparticles before and after Immobilization of Collagen Protease}

3.4.1. Particle Size Distribution Analysis. Determination of particle size distribution of SPS nanospheres is shown in Figure 9. Their average particle size is $155.1 \mathrm{~nm}$, and the multidispersion index is 0.296 . 


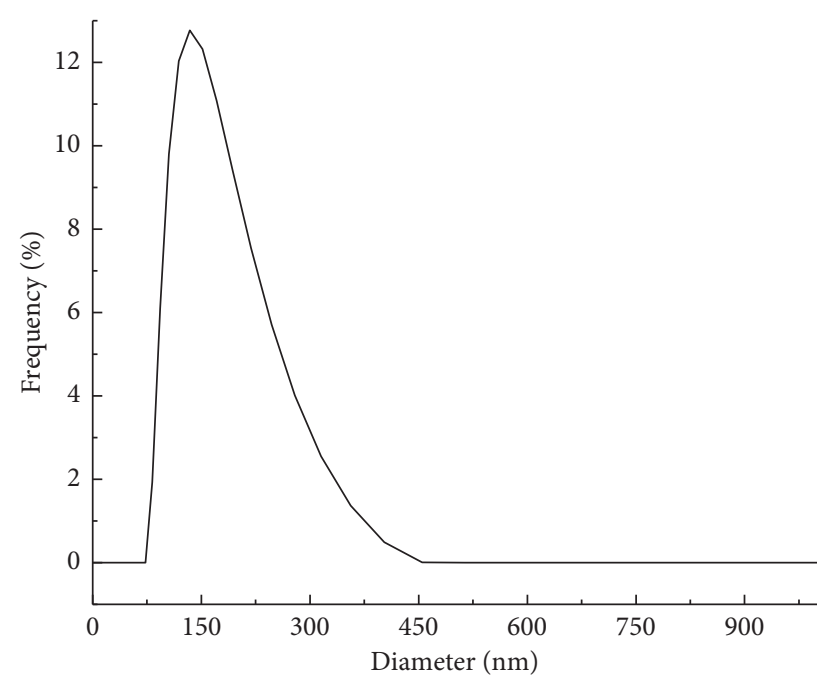

FIGURE 9: Granularity diagram of SPS nanoparticles.

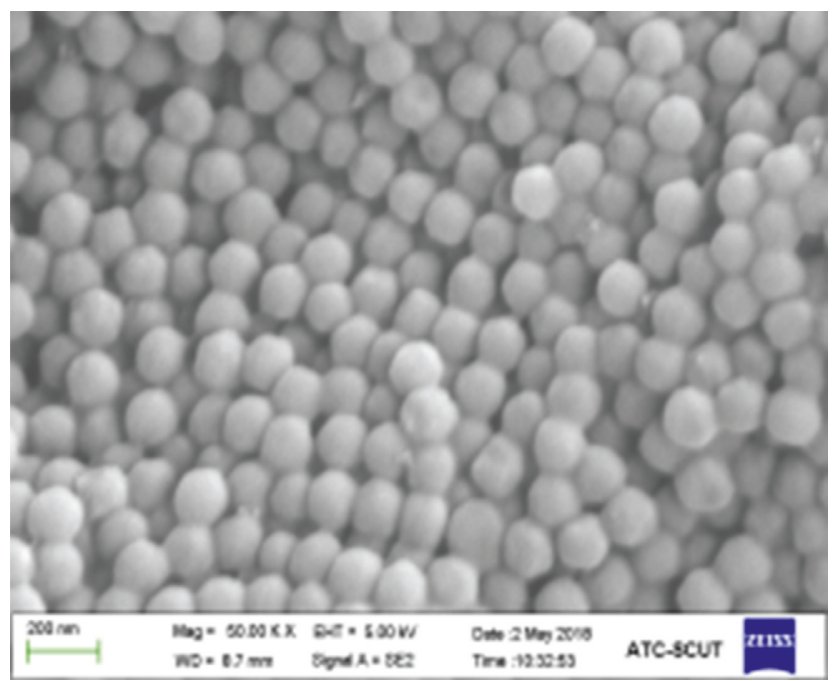

(a)

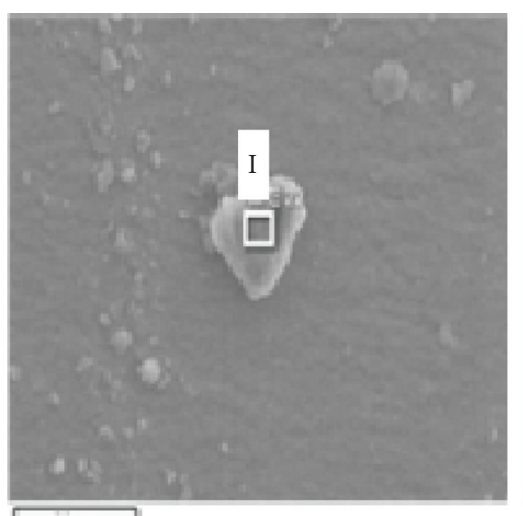

$50 \mu \mathrm{m}$

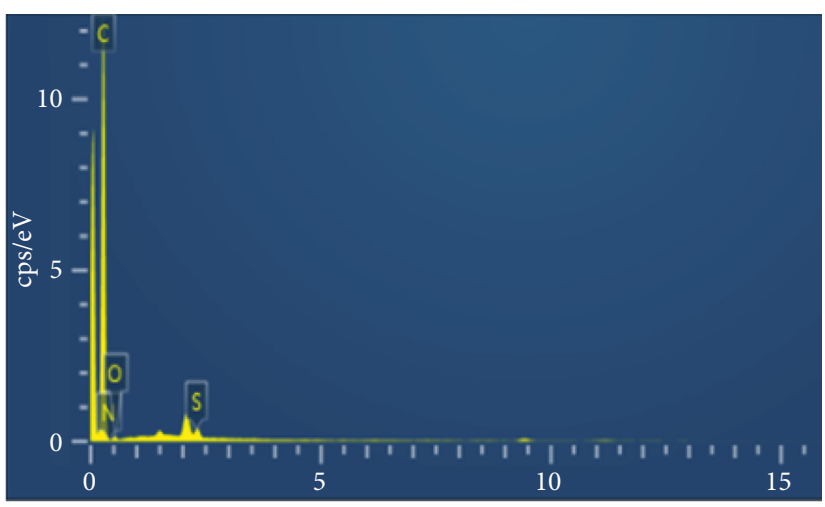

(b)

FIGURE 10: (a) SEM diagram of SPS nanoparticles before immobilization. (b) EDS spectrogram of SPS nanoparticles before immobilization. 


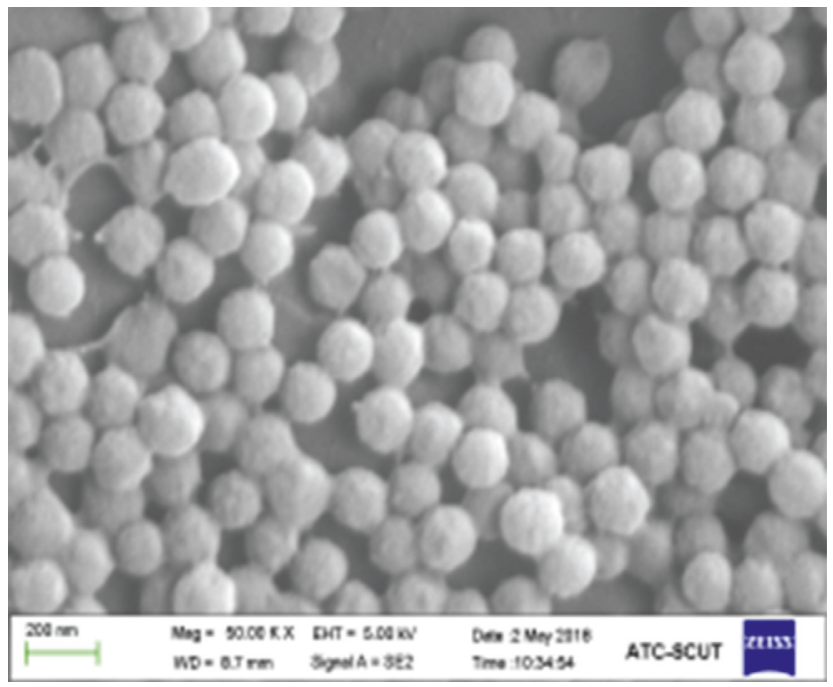

(a)
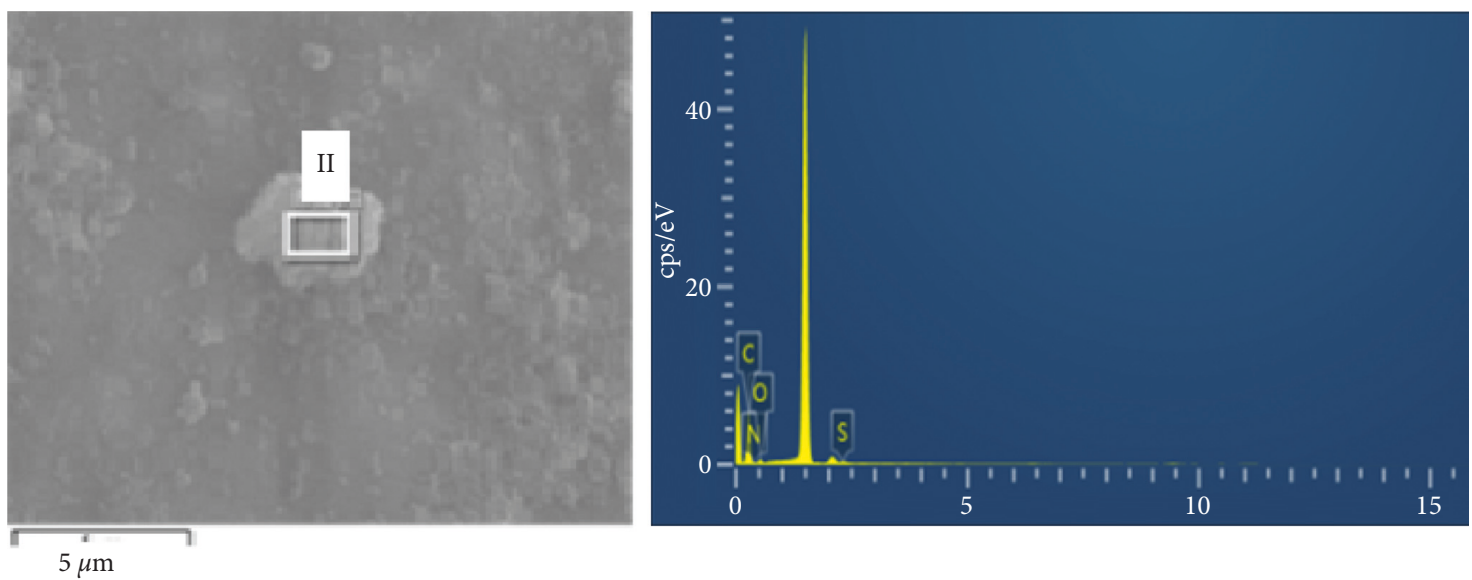

(b)

FIGURE 11: (a) SEM diagram of SPS nanoparticles after immobilization. (b) EDS spectrogram of SPS nanoparticles after immobilization.

TABLE 5: Energy spectrum elements of sulfonated polystyrene nanospheres before and after immobilization.

\begin{tabular}{|c|c|c|c|c|c|}
\hline Element (before immobilization) & wt.\% & at.\% & Element (after immobilization) & wt.\% & at.\% \\
\hline $\mathrm{C}$ & 95.24 & 96.84 & $\mathrm{C}$ & 73.65 & 78.24 \\
\hline $\mathrm{N}$ & 0.00 & 0.00 & $\mathrm{~N}$ & 10.09 & 9.19 \\
\hline $\mathrm{O}$ & 3.52 & 2.68 & $\mathrm{O}$ & 15.27 & 12.18 \\
\hline S & 1.24 & 0.47 & S & 0.99 & 0.39 \\
\hline Total & 100.00 & 100.00 & Total & 100.00 & 100.00 \\
\hline
\end{tabular}

3.4.2. SEM Observation and Energy Spectrum Analysis. A set of scanning electron microscopy and energy spectrum tests about SPS nanoparticles before and after immobilization are shown in Figures 10 and 11. It can be observed from the figures that the SPS nanoparticles have an obvious spherical shape, uniform size, uniform distribution, and good monodispersity. The surface of the nanospheres is smooth before immobilization and rough after immobilization [30], which indicates that collagen hydrolase has been successfully immobilized onto the surface of SPS nanospheres. According to the energy spectrum test results in Table 5, the SPS nanospheres before immobilization contain $\mathrm{C}, \mathrm{O}$, and $\mathrm{S}$ elements, of which the content of $\mathrm{C}$ is the highest and the content of $\mathrm{O}$ and $\mathrm{S}$ is significantly less. The $\mathrm{S}$ element is caused by the introduction of a sulfonic acid group when the concentrated sulfuric acid is sulfonating polystyrene, indicating that the immobilized material is successfully sulfonated polystyrene. The nanoparticles after immobilization contain $\mathrm{C}, \mathrm{N}, \mathrm{O}$, and $\mathrm{S}$ elements. Compared with those before immobilization, the $\mathrm{C}$ element content is decreased, while the $\mathrm{N}$ and $\mathrm{O}$ contents are significantly increased and the $\mathrm{S}$ content is less changed of the immobilized nanospheres [31]. This further indicates that collagenase has been successfully immobilized onto SPS nanospheres. 


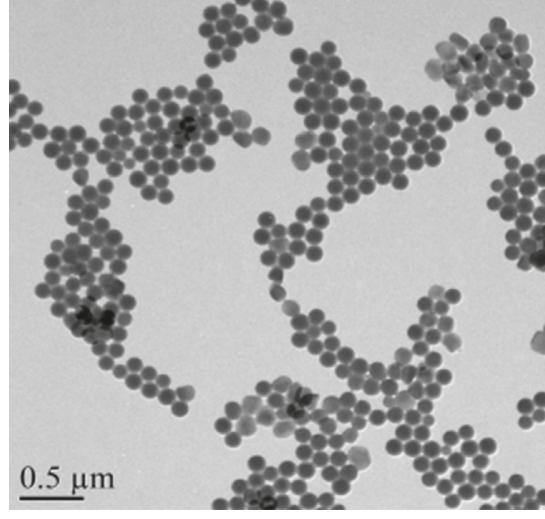

(a)

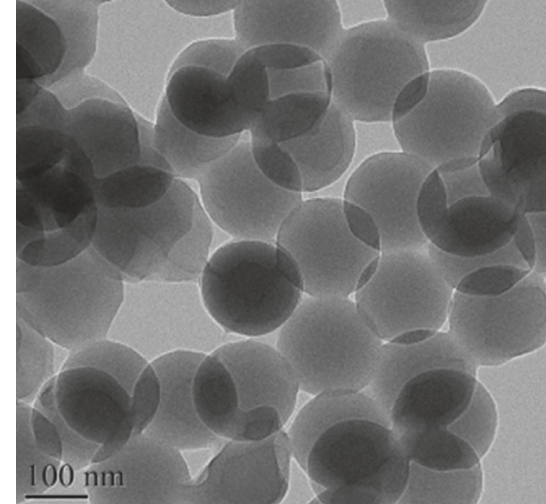

(b)

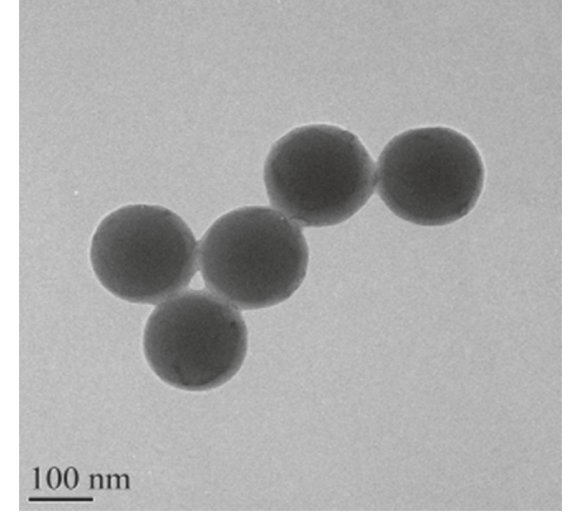

(c)

FIgURE 12: Transmission electron microscopy (TEM) before immobilization of collagenase onto SPS nanospheres.
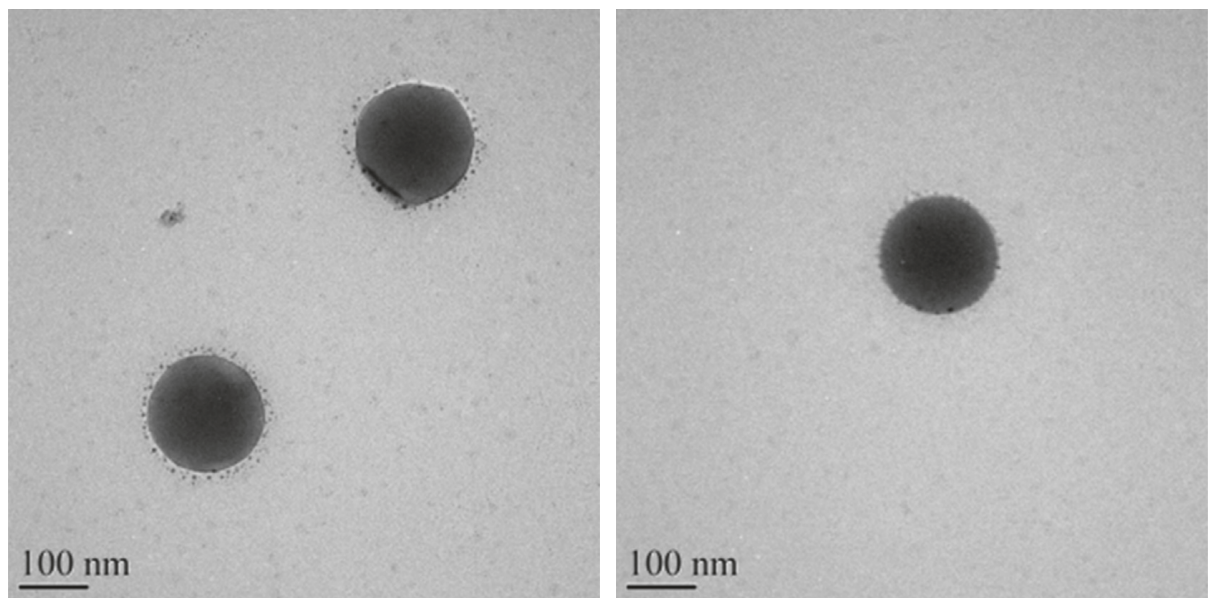

FIgURE 13: Transmission electron microscopy (TEM) after immobilization of collagenase onto SPS nanospheres.

3.4.3. TEM Analysis. The TEM images of the SPS nanospheres before and after immobilization of collagen hydrolase are shown in Figures 12 and 13. It can be clearly seen from Figure 12 that the SPS nanospheres before immobilization have regular spherical shapes with uniform size, smooth surface, no impurities, homogeneous distribution, and good monodispersity. According to Figure 13, the surface of SPS nanospheres adsorbed some particles and became rough, which also indicates that the collagen hydrolase is successfully immobilized onto the surface of the SPS nanospheres.

3.4.4. FT-IR Spectroscopy Analysis. It can be observed from Figure 14 that the infrared spectrum of the SPS nanospheres before and after the collagen hydrolase immobilization has similarities and obvious differences. The infrared spectra show that the characteristic absorption peaks of $\mathrm{O}-\mathrm{H}$ bonds of aromatic compounds appear at about $3400 \mathrm{~cm}^{-1}$, the stretching vibration peaks of $\mathrm{C}-\mathrm{H}$ bonds appear at $2900 \mathrm{~cm}^{-1}$, and the vibration absorption peaks of C-O appear at $1645 \mathrm{~cm}^{-1}$. In addition, the characteristic peaks of sulfonic acid groups appear at 1122 and $1029 \mathrm{~cm}^{-1}$ [32].

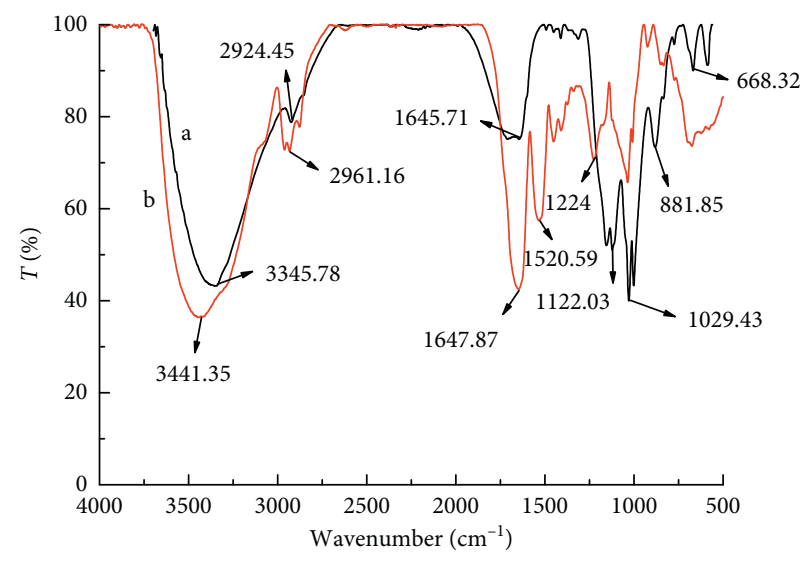

FIGURE 14: Infrared spectrum of SPS nanospheres (a) and immobilized enzymes (b).

However, only the infrared spectrum of the immobilized enzyme shows a characteristic absorption peak of the amino group at $1520 \mathrm{~cm}^{-1}$, and the peak at $1647 \mathrm{~cm}^{-1}$ of the fixed enzyme is significantly enhanced [33]. Therefore, the infrared suggests that collagen hydrolase has been successfully 
immobilized onto SPS nanospheres, which is consistent with the expected results.

\section{Conclusions}

(1) In this paper, an alkaline collagen from fermentation of Bacillus subtilis was isolated, purified, and identified, and its structure was simulated. The molecular weight of the purified enzyme protein was $31.0 \mathrm{kDa}$ determined by SDS-PAGE gel electrophoresis. By LC-MS-MS sequencing and structure simulation online, the amino acid sequence and one three-dimensional structure simulation diagram of the purified enzyme protein were obtained. The sequence consistency was $64.04 \%$, which suggested that the protein might belong to the subtilisin protease family. Homologous modeling is the main method to construct the three-dimensional structure of the protein. Analysis of the protein database PDB leads to the conclusion that any pair of proteins, if their sequence consistency is more than $30 \%$, has a similar three-dimensional structure; that is, the basic folding of the two proteins is the same, and only some of the details in the nonspiral and nonfolded lamellar regions are different. For the sequences consistent with $60 \%$ parts, the 3D models determined by the homologous modeling method are very accurate. If their sequence consistency exceeds $60 \%$, the construction results will be close to the test results obtained from the experiment [34]. The purpose of three-dimensional structure simulation for the enzyme protein using the resources in the protein database in this paper is to obtain some important reference information for the study of the structure and function of the enzymes. On the basis of this study, combining with the classical biochemical knowledge, we will analyze the enzyme protein from the essence, predict its function from the structure, compare the function with the similar enzyme protein, and hope to find a substitute enzyme.

(2) The SPS nanospheres before and after immobilization were analyzed by particle size distribution, SEM, EDS, TEM, and Fourier transform infrared spectroscopy, indicating that the average particle size of the SPS nanospheres was $155.1 \mathrm{~nm}$ and collagen hydrolase was successfully immobilized onto SPS nanospheres.

(3) The optimum immobilization conditions obtained by the orthogonal test are as follows: volume ratio of the immobilization carrier to the enzyme was $3: 50$ $(\mathrm{mL}: \mathrm{mL})$, the immobilization temperature was $25^{\circ} \mathrm{C}$, and the $\mathrm{pH}$ was 4.5 . At this time, the protein immobilization ratio was $73.48 \%$, and the immobilized enzyme specific activity was $274.05 \mathrm{U} / \mu \mathrm{g}$. Compared with the specific activity $(509.90 \mathrm{U} / \mu \mathrm{g})$ of the free enzyme, the specific activity of the immobilized enzyme was about $53.74 \%$ that of the free enzyme, indicating that the immobilization of
SPS nanospheres under the optimum conditions would reduce the enzymatic activity of collagenase. As a new immobilization carrier, SPS nanospheres can immobilize collagen hydrolase effectively with a simple and easy operation process, which has good practical application prospect and significance for large-scale industrial production, with mild immobilized conditions, and with low cost. Although only the conditions of the enzyme immobilized by SPS nanospheres have been studied in this paper, we have also systematically studied the application conditions and properties of immobilized enzymes, and the results will be reported in the near future.

\section{Data Availability}

The data used to support the findings of this study are available from the corresponding author upon request.

\section{Conflicts of Interest}

The authors declare that they have no conflicts of interest.

\section{Acknowledgments}

This work was financially supported by the Science and Technology Planning Project of Guangdong Province (2015B020230001), the Project of Food Science Innovation Team of Guangdong Higher Education Institutes (2016KCXTD020), and the Guangdong University of Petrochemical Technology 2018 University-Level Cultivation Project for College Students' Innovation and Entrepreneurship (2018pyA039).

\section{References}

[1] P. Banerjee, L. Suguna, and C. Shanthi, "Wound healing activity of a collagen-derived cryptic peptide," Amino Acids, vol. 47, no. 2, pp. 317-328, 2015.

[2] E. J. Lee, J. Hur, S. A. Ham et al., "Fish collagen peptide inhibits the adipogenic differentiation of preadipocytes and ameliorates obesity in high fat diet-fed mice," International Journal of Biological Macromolecules, vol. 104, pp. 281-286, 2017.

[3] Y. Bu, J. Elango, J. Zhang et al., "Immunological effects of collagen and collagen peptide from blue shark cartilage on 6TCEM cells," Process Biochemistry, vol. 57, pp. 219-227, 2017.

[4] P. Selvakumar, T. C. Ling, A. D. Covington, and A. Lyddiatt, "Enzymatic hydrolysis of bovine hide and recovery of collagen hydrolysate in aqueous two-phase systems," Separation and Purification Technology, vol. 89, pp. 282-287, 2012.

[5] L. Ma, Isolation and Enzyme Characteristics of a Strain Producing Collagenase, Dalian Polytechnic University, Dalian, China, 2012.

[6] J. D. Maclennan, I. Mandl, and E. L. Howes, "Bacterial digestion of collagen," Journal of Clinical Investigation, vol. 32, no. 12, pp. 1317-1322, 1953.

[7] R. A. Cai, H. Li, L. Y. Li, and L. P. Zhang, "Physiological function property and applications of collagen protein," Meat Industry, vol. 1, pp. 7-9, 2010. 
[8] W. B. Sun, Marine Microorganisms Source Collagenase Enzyme System Research, Dalian Polytechnic University, Dalian, China, 2014.

[9] J. Betbel and G. R. Naik, "Studies on production of thermostable alkaline protease from thermophilic and alkaliphilic Bacillus sp. JB-99 in a chemically defined medium," Process Biochemistry, vol. 37, no. 2, pp. 139-144, 2001.

[10] X. Yang, X. Xiao, D. Liu et al., "Optimization of collagenase production by Pseudoalteromonas sp. SJN2 and application of collagenases in the preparation of antioxidative hydrolysates," Marine Drugs, vol. 15, no. 12, p. 377, 2017.

[11] M. K. Walsh and R. Rastal, "Immobilized enzyme technology for food applications," in Novel Enzyme Technology For Food Applications, pp. 60-84, Taylor \&, Francis, London, UK, 2007.

[12] J. Jiang, P. Wang, and D. Hou, "The mechanism of cesium ions immobilization in the nanometer channel of calcium silicate hydrate: a molecular dynamics study," Physical Chemistry Chemical Physics, vol. 19, no. 41, pp. 27974-27986, 2017.

[13] K. Zhao, J. Zhao, C. Wu et al., "Fabrication of silver-decorated sulfonated polystyrene microspheres for surface-enhanced Raman scattering and antibacterial applications," RSC Advances, vol. 5, no. 85, pp. 69543-69554, 2015.

[14] J. Wang, D. Wu, G. Zhao et al., "Reversible immobilization of glucoamylase onto magnetic polystyrene beads with multifunctional groups," Process Biochemistry, vol. 49, no. 5, pp. 845-849, 2014.

[15] A. M. Al-Sabagh, Y. M. Moustafa, A. Hamdy, H. M. Killa, and R. E. Morsi, "Preparation and characterization of sulfonated polystyrene/magnetite nanocomposites for organic dye adsorption," Egyptian Journal of Petroleum, vol. 27, no. 3, pp. 403-413, 2017.

[16] L. Chen, Purification and Characterization of a Collagenase from Bacillus Pumilus, Sichuan Agricultural University, Yaan Shi, China, Master degree, 2008.

[17] Z. L. Zeng, R. H. Xu, and T. Xiong, "Purification of Alliinase and determination of its enzymatic properties," Food Science, vol. 29, no. 12, pp. 431-434, 2008.

[18] Y. Li, Purify the Collagenase from Bacillus Cereus R75E and Its Recombinant Rxpression in Pichia pastoris, Tianjin University of Commerce, Tianjin, China, 2016.

[19] N. Ahmadifard, J. H. C. Murueta, A. Abedian-Kenari, A. Motamedzadegan, and H. Jamali, "Comparison the effect of three commercial enzymes for enzymatic hydrolysis of two substrates (rice bran protein concentrate and soy-been protein) with SDS-PAGE," Journal of Food Science and Technology, vol. 53, no. 2, pp. 1279-1284, 2016.

[20] F. Lottspeich, "Proteomics-an unexpected journey into the complexity of protein structures and functions," EuPA Open Proteomics, vol. 21, pp. 1-2, 2018.

[21] A. Fiser, "Protein structure modeling in the proteomics era," Expert Review of Proteomics, vol. 1, no. 1, pp. 97-110, 2004.

[22] L. W. Ding, H. Li, C. X. Wang, P. Li, L. Zhang, and Z. B. Wen, "The preparation and characterization of polystyrene submicrospheres," Journal of Jiangxi Normal University, vol. 42, no. 2, pp. 155-159, 2018.

[23] A. Matin, E. Elena, T. Laptinskaya, and S. Klimonsky, "Selfassembly of polystyrene microspheres into two-level hierarchical structures," Superlattices and Microstructures, vol. 120, pp. 806-811, 2018.

[24] Y. G. Tao, S. X. Zheng, Z. Y. Jiang, L. B. Zhu, G. C. Du, and M. D. Liang, "Interfacial characterization between biomimetic adhesion nano $\mathrm{TiO}_{2}$ and lipase," New Chemical Materials, vol. 44, no. 8, pp. 156-158, 2016.
[25] L. Zhang, C. W. Shi, C. H. Li, W. X. Wang, J. Q. Mo, and Y. B. Shao, A Method for the Determination of Collagen Peptide in Tilapia by Biuret Method, CN 108827945A, 2018, http://dbpub.cnki.net/grid2008/dbpub/detail.aspx?dbcode= SCPD\&dbname $=$ SCPD2018\&filename $=$ CN108827945A\&uid $=$ WEEvREdxOWJmbC9oM1NjYkZCbDdrdVRVRFFQajIwelgval NqM25pWS9GeVk=\$R1yZ0H6jyaa0en3RxVUd8df-oHi7XMM Do7mtKT6mSmEvTuk11l2gFA!!.

[26] H. T. Gao and X. H. Ma, "Emulsion polymerization of polystyrene (PS) polymer microspheres and characterization," New Chemical Materials, vol. 41, no. 7, pp. 91-92, 2013.

[27] X. Y. Du and L. P. Geng, "Preparation and characterization of $\mathrm{Fe}_{3} \mathrm{O}_{4} /$ Polystyrene composite particles," Material Review, vol. 24, no. 1, pp. 170-176, 2010.

[28] W. Han, X. Q. Xu, X. Y. Ye, and J. Lin, "Purification and characterization of the alginate lyase isolated from marine," Journal of Fuzhou University, vol. 46, no. 1, 2018.

[29] J. Yang, Y. J. Zou, R. Y. Zhang, and Q. X. Hu, "Purification and property of laccase from Pleurotus eryngii var. tuoliensis," Mycosystema, vol. 34, no. 3, pp. 456-464, 2015.

[30] Q. Qiu, J. H. Cha, Y. W. Choi, J. H. Choi, J. Shin, and Y. S. Lee, "Preparation of polyethylene membranes filled with crosslinked sulfonated polystyrene for cation exchange and transport in membrane capacitive deionization process," Desalination, vol. 417, pp. 17-19, 2017.

[31] M. A. Abdel-Naby, "Immobilization of Paenibacillus macerans NRRL B-3186 cyclodextrin glucosyltransferase and properties of the immobilized enzyme," Process Biochemistry, vol. 34, no. 4, pp. 103-107, 1999.

[32] J. Wang, F. M. Zhu, J. C. Liu, H. M. Li, and S. G. Lin, "Characterization of sulfonated syndiotactic polystyrene," Acta Macromolecule, vol. 22, no. 2, pp. 250-253, 2001.

[33] K. Zhao, Q. J. Di, L. Deng, and F. Wang, "Synthesis and characterization of the immobilized lipase with adsorption and cross-linking," Modern Chemical Industry, vol. 36, no. 12, pp. 63-68, 2016.

[34] H. B. Wen, W. R. Jing, D. L. Yang, L. P. Liu, and Z. Q. Wang, "Screening and characterization of an thermophilic alkaline crude protease from an isolated strain of Bacillus subtilis I15," Journal of Zhengzhou University, vol. 31, no. 1, pp. 70-73, 2010. 


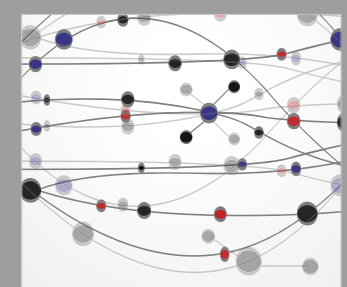

The Scientific World Journal
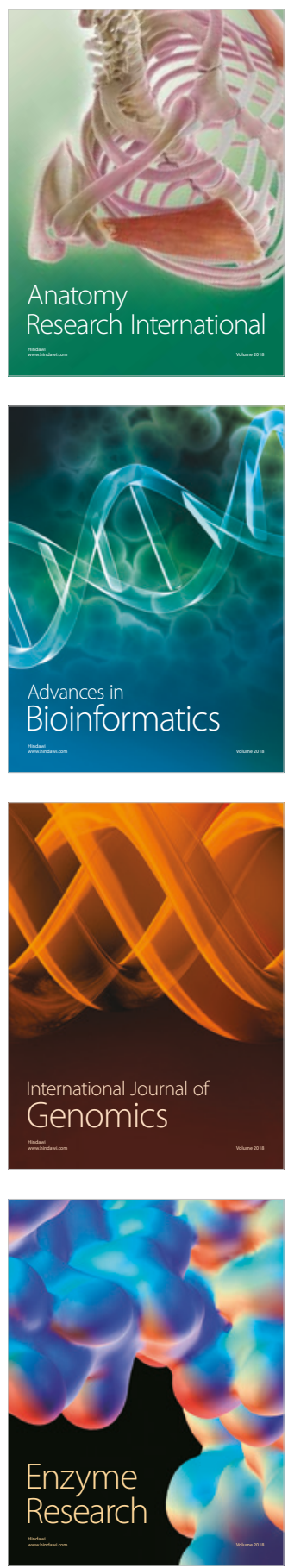
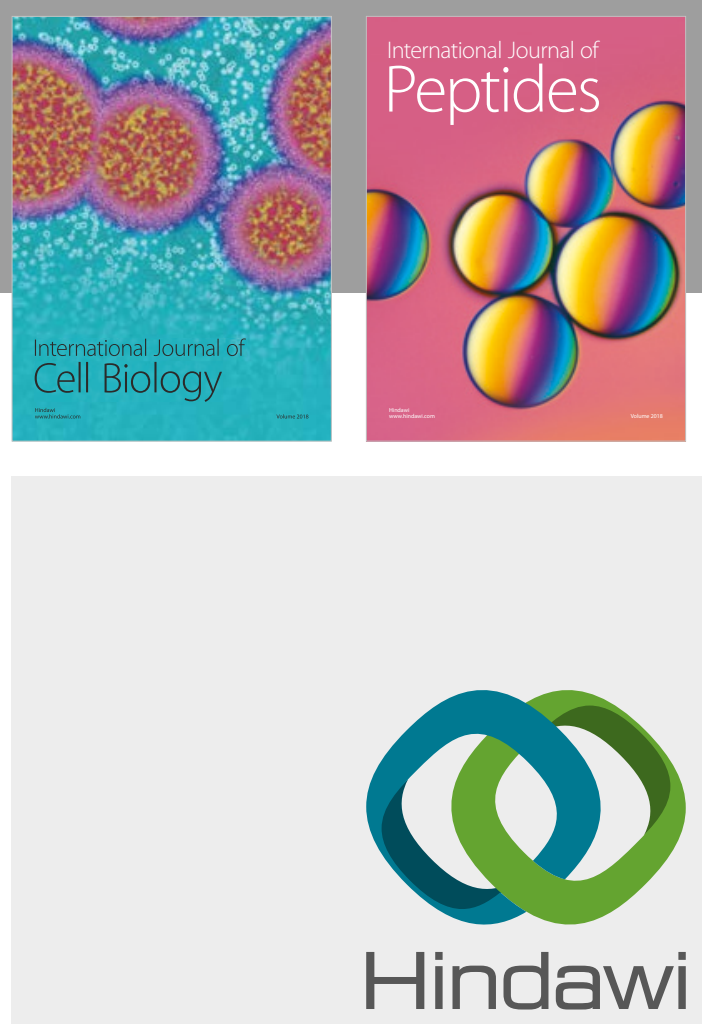

Submit your manuscripts at

www.hindawi.com
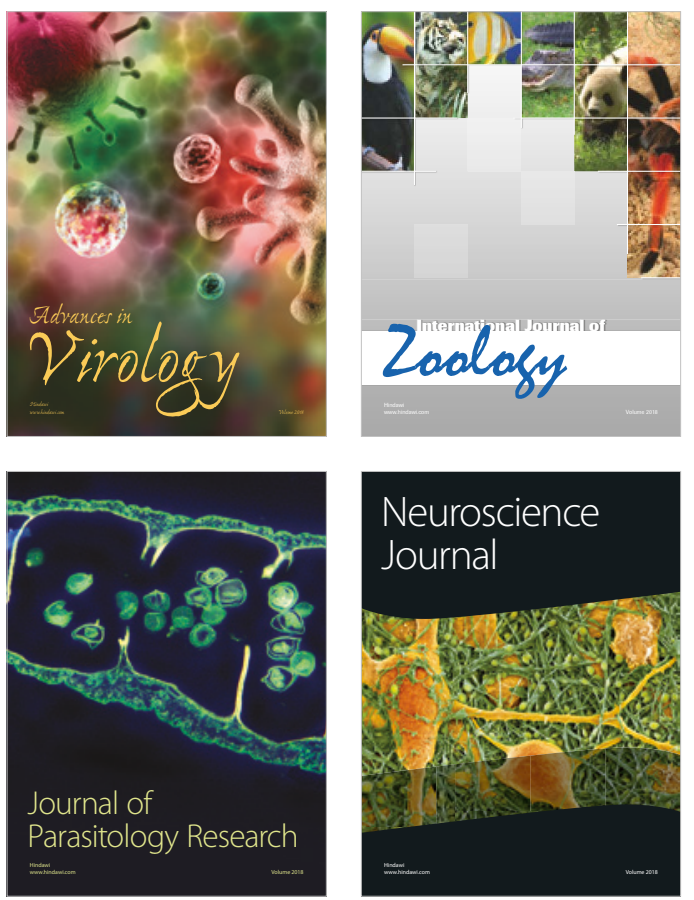
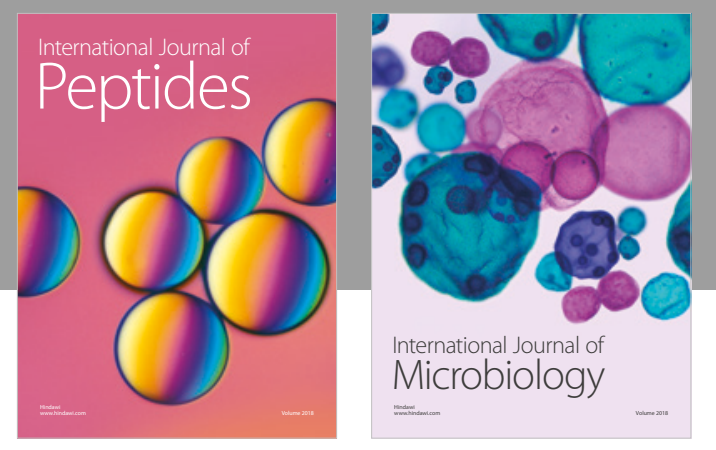

nternational Journal of Microbiology
Journal of
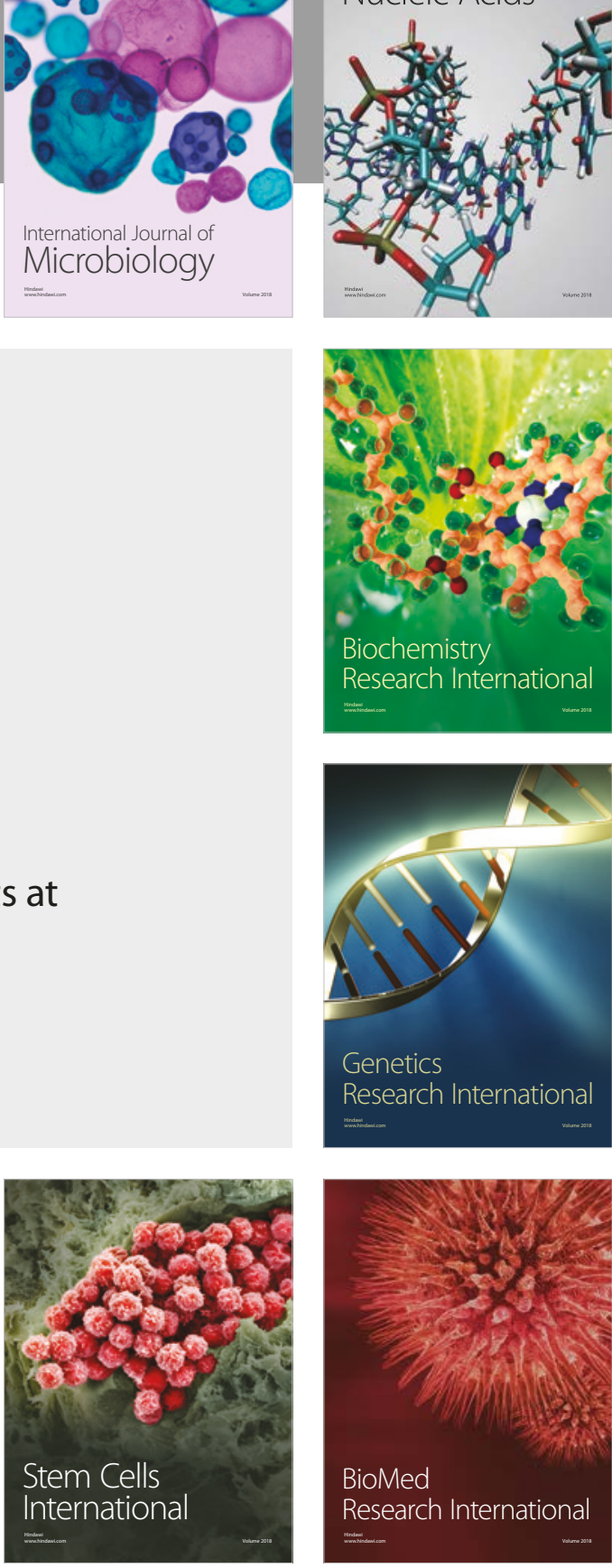
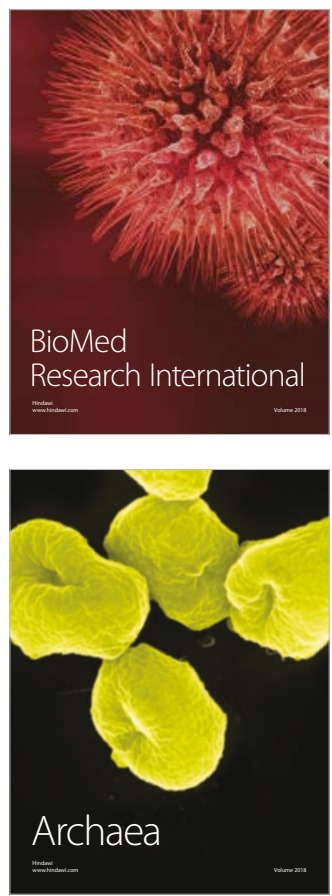